\title{
Na cmentarzysku polonistycznych podręczników - kilka myśli
}

\section{At the cemetery of Polish language textbooks - a few thoughts}

\author{
Zenon Uryga
Uniwersytet Pedagogiczny im. KEN, Kraków
}

\begin{abstract}
School literature textbooks, marked by the risk of impermanence by educational reforms, are noteworthy documents of teaching creativity. In the research approach, the historical and cultural perspective of assessing their role in the transformation of horizons and methods of Polish language education is not enough. One should also take into account the praxeological dimension: devote attention to the creative role of the didactic imagination of the authors in building the textbook as a project for specific educational activities. In this respect, significant changes can now be seen in the understanding of the handbook's relationship to "live teaching" acts. Textbooks by professional literature researchers are in line with the tradition of complementary lesson outlines of historical and literary knowledge of the subject, limiting didactic obligations to comply with the principles of clarity and accessibility of the message, and (sometimes) student-oriented narrative style. In contrast, innovative textbook constructions, which are created by the initiative of teaching teams in the vicinity of the school workshop, focus attention on the design of a tool to support the work of teachers and students, reaching for the experience of Polish speakers and appealing in different ways to their didactic imagination. The value of a textbook constructions created in this way is in many cases balanced with the achievements of scientific works. One should reach for them in educating Polish students.

Key words: school textbooks/handbooks, didactic imagination, outline of historical and literary knowledge, tool of Polish language education
\end{abstract}

Streszczenie: Szkolne podręczniki literatury, naznaczone przez reformy edukacyjne ryzykiem nietrwałości, stanowią godne uwagi dokumenty nauczycielskiej twórczości. W badawczym do nich podejściu nie wystarczy historyczno-kulturowa perspektywa oceny ich roli w przemianach horyzontów i metod kształcenia polonistycznego. Trzeba również uwzględnić wymiar prakseologiczny: poświęcić uwagę twórczej roli wyobraźni dydaktycznej autorów w budowaniu podręcznika jako projektu określonych działań edukacyjnych. Pod tym względem można obecnie obserwować istotne zmiany w pojmowaniu relacji podręcznika wobec aktów „żywego nauczania”. Podręczniki autorstwa profesjonalnych badaczy literatury pozostają w zgodzie z tradycją uzupełniających działania lekcyjne zarysów wiedzy historycznoliterackiej o przedmiocie, ograniczających zobowiązania dydaktyczne 
do przestrzegania zasad jasności i przystępności przekazu oraz (niekiedy) zorientowanego na ucznia stylu narracji. Natomiast nowatorskie konstrukcje podręcznikowe, które powstają z inicjatywy zespołów nauczycielskich w bliskości szkolnego warsztatu, skupiają uwagę na projektowaniu narzędzia wspomagającego pracę nauczyciela i uczniów, sięgając do doświadczeń polonistów i apelując na różne sposoby do ich wyobraźni dydaktycznej. Wartość tak tworzonych konstrukcji podręcznikowych w wielu przypadkach równoważy się z osiągnięciami prac naukowych. Należy do nich sięgać w kształceniu polonistów.

Słowa kluczowe: szkolne podręczniki literatury, wyobraźnia dydaktyczna, zarys wiedzy historycznoliterackiej, narzędzie kształcenia polonistycznego

Propozycja wejścia na rozległy cmentarz szkolnych podręczników nie powinna dziwić polonistycznych dydaktyków, bo wiąże się w istotny sposób z potrzebą myślenia o przemijaniu pokoleń nauczycieli oraz przemianach idei, metod i narzędzi kształcenia. Nie o to w niej jednak chodzi, by odwiedzić najbardziej okazałe podręcznikowe pomniki, zatrzymać się przy innych znaczących nagrobkach czy też odkryć te mniejsze, zgoła zapomniane, choć godne uwagi mogiłki. Zamierzenie jest inne: myślę, że na tej szczególnej nekropolii warto poświęcić chwilę ogólniejszej refleksji nad fenomenem i ryzykiem twórczości podręcznikowej.

Żywot polonistycznych podręczników jest nietrwały, nieobliczalny. Zależy od biegu i zakrętów historii, od uwarunkowań cywilizacyjno-kulturowych, od przemian myśli pedagogicznej oraz edukacyjnej strategii, zaś szczególnie od reform szkolnych dobrze lub źle przygotowanych, a nierzadko od ideologicznych zwrotów i kaprysów władz oświatowych. Mamy żywo w pamięci niedawny zgon całej generacji gimnazjalnych podręczników, a w oczach widok innych, skazanych aktualnymi przekształceniami szkoły na uwiąd i bezużyteczność.

Gdyby się na chwilę zatrzymać przy tej ostatniej, zbiorowej mogile, trudno byłoby się oprzeć refleksji nad marnotrawieniem twórczej energii nauczycieli - autorów wielu zbudowanych zespołowymi wysiłkami podręczników. Bo przecież było czymś niezwyczajnym, świadczącym dowodnie o nauczycielskiej woli i gotowości odnowienia horyzontów i metod kształcenia, pojawienie się równoległe u progu gimnazjum aż 17, a w następnych latach dalszych 11 oryginalnych konstrukcji podręcznikowych, obudowanych metodycznie cyklów narzędzi pracy nauczyciela i uczniów w trzech kolejnych klasach nowego typu szkoły. Po likwidacji gimnazjum i po zmianie struktury liceum pozostaje nam tylko analizować te konstrukcje jako dokumenty nauczycielskiej twórczości.

Podobny, choć nie zawsze tak dramatyczny, bywa los innych, nierzadko nowatorskich dydaktycznie podręczników, które z różnych względów (np. zmian programów kształcenia, listy lektur, decyzji władz szkolnych, konkurencji wydawniczej itp.) nie znajdują trwałego miejsca w obiegu szkolnym. Wymiana jednych podręczników na inne, jak też i częste modyfikacje kolejnych wydań książek są na ogół postrzegane w szkolnej praktyce jako naturalne, rutynowe przystosowywanie narzędzi pracy do aktualnych wymagań 
programowych. Na refleksję nad podręcznikami jako szczególnego rodzaju dziełami myśli i wyobraźni dydaktycznej nie starcza zwykle czasu - sumowanie doznań i doświadczeń obcowania z nimi wymaga dystansu, a także badawczego nastawienia wobec praktyki działania nauczycielskiego.

Taki badawczy dystans pojawia się dopiero w licznych zorientowanych historycznie studiach, poświęcających uwagę wielu różnym dziewiętnastoi dwudziestowiecznym inicjatywom tworzenia podręczników polonistycznych. Rzucają one sporo światła na twórcze pomysły i działania autorów, ale skupiają przede wszystkim uwagę na podręcznikach jako dokumentach oświatowych, świadectwach określonych idei i dążeń edukacyjnych, poddają analizie ich zakorzenienie w pedagogicznych ideach danej epoki bądź ocenie ich roli wychowawczej oraz wpływu na poziom kultury i życia społecznego. Problematyka konstrukcji dzieł podręcznikowych jako narzędzi uczenia się i nauczania ustępuje tu miejsca ogólniejszej refleksji nad spełnianymi przez nie funkcjami kulturowymi.

Z obszaru badań nad dziejami polonistycznej dydaktyki warto przypomnieć kilka różnie sprofilowanych inicjatyw badawczych:

To na przykład obszerne, powstałe w latach 50. ubiegłego wieku, studium Wiktora Czerniewskiego (Czerniewski 1960, 9-113) poświęcone analizie wartości dydaktycznych znakomitych dzieł podręcznikowych, jak: Historia literatury niepodległej Polski Ignacego Chrzanowskiego, Historia literatury polskiej wieku XIX Lucjusza Komarnickiego, Zarys dziejów literatury polskiej Juliusza Kleinera i inne, dziś już obecne tylko w obiegu badawczym. Ujmuje ono badany problem i dokonuje oceny dzieł na gruntownie rozpoznanym tle ówczesnego rozwoju teorii podręcznika szkolnego

To z kolei różne prace o nauczaniu języka polskiego w szkole dziewiętnastowiecznej. Liczne artykuły i książki Lecha Słowińskiego (zob. np. Słowiński 1976) poświęcone podręcznikom doby zaborowej, w tym zwłaszcza praktyce twórczej i wydawniczej dydaktyków poznańskich (m.in. Hipolita Cegielskiego z jego Nauka poezji i braci Poplińskich), praktyce skupionej na budowaniu narzędzi kształcenia podtrzymujących poczucie polskości w trudnych warunkach kulturowej opresji zaborcy. Podobnie studia skupionych wokół Mieczysława Inglota badaczy wrocławskich, którzy w treściach niepozornych, dawno już zapomnianych wypisów dla szkół galicyjskich doby autonomicznej umieli odkryć interesującą obecność szyfru narodowej i społecznej symboliki (zob. Literatura i wychowanie, 1983).

To wreszcie książka Janusza Marchewy (Marchewa 1990) i studia innych dydaktyków (Słowiński 1991, Wichary 1991) odsłaniające na materiale międzywojennych podręczników dla szkół średnich zjawiska różnicowania się koncepcji kształcenia literackiego: odwrotu od tradycji historycznoliterackich zarysów ku konstrukcjom monograficznym (lekturoznawczym), kulturoznawczym, zorientowanym psychologicznie, literacko-prezentystycznym. Obraz tych zjawisk dopełniła i wzbogaciła książka Zofii Budrewicz (Budrewicz 2003), poświęcona słynnemu cyklowi wypisów 
gimnazjalnych Juliusza Balickiego i Stanisława Maykowskiego (Kraj lat dziecinnych, Będziem Polakami, Miej serce), budowanemu z tekstów specjalnie zamawianych u współczesnych pisarzy.

Przywołane tu studia łączy podobna perspektywa oglądu i wartościowania dawnych podręczników - powiązane z opisem ich walorów dydaktycznych spojrzenie historyczno-kulturowe. Najwyraźniej ten literaturoznawczy $\mathrm{w}$ istocie punkt widzenia zarysował się $\mathrm{w}$ badaniach wrocławskiego zespołu:

Badacz kultury literackiej zwłaszcza czasów najnowszych nie może nie doceniać (...) wartości dokumentu, jakim jest podręcznik odtwarzający podstawowe rysy jej obrazu. Interesować zaś go będą te warstwy podręcznika języka polskiego czy też te jego części, dzięki którym szkoła wpływać może na kształt zespołu przeświadczeń dotyczących literatury oraz umiejętności obcowania z literaturą (Wichary 1979, 47).

Spojrzenie na podręcznik jako „komunikat, tekst utrwalający i pozwalający odczytać intencje wychowania przez literaturę i dla literatury" (Wichary 1979, 47), jest bez wątpienia sprawnym metodologicznie kluczem w badaniach nad dziejami kształcenia polonistycznego. Może także stanowić dogodną podstawę dla literaturo- i kulturoznawczo zorientowanych analiz współczesnych podręczników, ale nie otwiera drogi do poznawania ich wartości jako narzędzi uczenia się i nauczania. Na konstrukcję podręcznika wypada więc spojrzeć również z innej - prakseologicznej perspektywy.

Ciśnienie sytuacji nieustannego reformowania struktur szkoły i programów nauczania sprawia, że wraz z kolejnymi zmianami mnożą się nowe inicjatywy tworzenia podręczników. Narasta potrzeba myślenia o kształcie dydaktycznym tych narzędzi pracy ucznia i nauczyciela - recenzowania ich projektów w fazie wydawniczej, ocen warunkujących dopuszczenie do użytku szkolnego, a wreszcie opiniowania ich wartości i przydatności przez użytkowników - nauczycieli i znawców przedmiotu.

Za znamienny sygnał zwrotu ku pragmatycznej orientacji myślenia o podręcznikach, ich tworzeniu można uznać prace krakowskiej Komisji PAU do Oceny Podręczników Szkolnych publikowane w 15 wydanych do tej pory tomach opinii o książkach do nauczania wszystkich szkolnych przedmiotów (w tym do języka polskiego). Inicjatywa PAU z 2001 roku miała na celu to, żeby przez krytyczną analizę podręczników, opartą na merytorycznych, dydaktycznych i edytorskich kryteriach, wspierać działania reformatorskie i wpływać na kształt przemian edukacyjnych. Wieloletnia, systematyczna realizacja tego zamierzenia, towarzysząca powstawaniu książek najpierw do liceum, później do gimnazjum, miała ograniczoną raczej skuteczność oddziaływania na praktykę z winy izolacji polityki edukacyjnej od głosów opinii naukowej. Niewątpliwym jednak efektem inicjatywy okazało się otwarcie pola refleksji naukowej nad konstrukcją podręcznika jako narzędzia uczenia się w reformowanej szkole. Tym samym wywołanie 
potrzeby krytycznego - bo w zmienionych gruntownie warunkach kulturowych - spojrzenia na wypracowane w początkach ubiegłego wieku tezy o istocie i funkcjach podręcznika.

W bezpośrednim kontakcie z nową generacją książek do języka polskiego dla liceum trudno już było akcentować dystans między podręcznikiem jako książką stanowiącą drugie obok nauczyciela źródło wiedzy, zawierającą wybór najważniejszych wiadomości, gotowych wyników badań z określonej dziedziny, a żywym nauczaniem (Ingarden 1939). Pogląd, że rolą podręcznika ma być uzupełnianie, a nie zastępowanie żywego nauczania, wchodził w konflikt z obserwacją współczesnej praktyki edukacyjnej, gdzie oto $\mathrm{z}$ dawniej nie uważanych za podręczniki wypisów i materiałów pomocniczych, wzbogacanych teraz o instrukcje pracy, pytania problemowe, wiadomości, ćwiczenia itp. zaczęły powstawać książki mające w rękach nauczyciela i uczniów stanowić ważne narzędzia pracy lekcyjnej.

Fundamentalne pytania teoretyczne o to, czym jest podręcznik, jakie są jego funkcje dydaktyczne i jaka zatem ma być jego struktura, wymagają już dzisiaj innych odpowiedzi. Ale wobec skali współczesnych przemian cywilizacyjnych trudno to wymaganie spełnić, zwłaszcza w odniesieniu do wielofunkcyjnego narzędzia służącego kształceniu polonistycznemu. Może więc zamiast poszukiwania zadowalającej definicji podręcznika warto się ograniczyć do obserwacji fenomenu podręcznikowej twórczości. Zastanawiać się nad motywacjami autorów podejmujących się ich budowania, pytać o sposób pojmowania zadań i horyzonty pedagogiczne, jakie im wyznaczają. Przyjąć zarazem w spojrzeniu na te dzieła perspektywę różną od literaturoznawczej, historyczno-kulturowej.

Podręcznik polonistyczny - postrzegany z perspektywy prakseologicznej jako narzędzie kształcenia - jest rodzajem planu działania dydaktycznego, propozycją potencjalnego doboru i układu czynności uczniów i nauczyciela, zjednoczonych wspólnym zamierzeniem uczenia się i pomagania w uczeniu się przedmiotu. W takim planie działania „to co istotne sprowadza się do opisu czynności składowych danego splotu lub tylko pasma działań ewentualnych, ze szczególnym uwzględnieniem ich doboru, kolejności czasowej, rozlokowania przestrzennego i rozmieszczenia wedle podmiotów poszczególnych działań składowych" (Kotarbiński 1973, 81).

Budowanie podręcznika jako planu, projektu określonych działań edukacyjnych jest niewątpliwie aktem twórczym, nawet gdy nieudanym. O wartości każdego z takich kreatywnych działań projektowych rozstrzyga współistnienie tak ważnych pierwiastków myślowych, jak świadomość celu projektu, wiedza o jego przedmiocie, znajomość uwarunkowań zamierzonego działania, a przede wszystkim wyobraźnia kreująca możliwą, pożądaną jego strukturę i funkcje. Różny poziom zharmonizowania tych pierwiastków staje się źródłem odmienności tworzonych konstrukcji.

W praktyce tworzenia podręczników polonistycznych rysuje się wyraźna, warunkowana pozycją zawodową i metodologicznymi orientacjami twórców, 
odmienność pojmowania zadań i pożądanych treści budowanego narzędzia, występują też różnice w postrzeganiu realiów i wymagań szkolnego warsztatu. Odmienne bywają sytuacje inicjujące działania twórcze, a także autorskie motywacje podejmowania prac nad podręcznikami.

Z tej perspektywy można by wskazać na dwie sytuacje, zgoła odmiennie rzutujące na kształt projektowanej książki :

- Sytuacja, gdy praca nad podręcznikiem ma źródło w warsztacie i doświadczeniu naukowym autora, wynika z chęci przekazania w przystępnej formie wiedzy o studiowanym przedmiocie i zaznaczenia swego poglądu na rolę i miejsce tej wiedzy w edukacji. Podjęcie pracy może się wiązać z silną potrzebą przekazywania własnych doświadczeń badawczych i dydaktycznych albo też z poczuciem powinności edukacyjnej uczonego i z jego zaangażowaniem w procesy kształcenia. Nierzadko jednak ma początek w konkretnym zamówieniu wydawniczym, co może wpływać na mniej swobodną, podporządkowaną różnym wymaganiom formę.

- Sytuacja, gdy jednostkowa lub zespołowa inicjatywa pracy nad podręcznikiem rodzi się w bliskości szkolnego warsztatu polonisty oraz wyrasta $\mathrm{z}$ chęci zaproponowania zmian $\mathrm{w}$ kierunku i metodach kształcenia. Może się ona realizować w kształcie nowatorskiej konstrukcji książki, korzystającej z inwencji autora, ale też może polegać na próbie ukonkretniania ogólnie tylko zarysowanej idei reformatorskiej, jej wypełniania treścią czerpanych z nauczycielskiego doświadczenia pomysłów pracy.

Wskazując na te dwie, pomijam wiele sytuacji innych, związanych z rutynowym ciągiem wydawniczym, zobowiązującym autorów do dokładnej realizacji zaleceń konkretnych programów nauczania w określonych szkołach i klasach, a zarazem niesprzyjającym dydaktycznej inwencji. Pomijam, bo chcę skupić myśl na wyrazistych przypadkach, które pozwolą zwrócić uwagę na to, jak istotną rolę ma do spełnienia w projektowaniu podręcznika wyobraźnia dydaktyczna twórców.

Usystematyzowane naukowo zarysy wiedzy o literaturze określonych epok nie wymagają w fazie projektowania szczególnego wysiłku wyobraźni dydaktycznej. Wyznacza im się tradycyjną rolę uzupełniania, utrwalania, poszerzania wiadomości wynoszonych z lekcji. Podręczniki mają zapewniać rzetelność naukową przekazu wiadomości, jego przystępność i przejrzystość, toteż wyobraźnia dydaktyczna autorów skupia się na rozdzielaniu analizy zjawisk od syntez, stosowaniu zabiegów rekapitulacji wiadomości, ćwiczeń utrwalających wiedzę, pytań sprawdzających zrozumienie itp.; czasem wprowadza wyjaśnienia na marginesach wykładu użytych terminów 
czy nowych pojęć, albo też reprodukcje obrazów korespondujące z informacjami wykładu. Niekiedy sięga po pomysły poprzedzania wykładowych informacji formułowaniem problemów aktywizujących myślenie uczniów.

Reszta wyobraźniowego potencjału szkolnych zarysów historycznoliterackich - trudno uchwytna - może tkwić w wewnętrznej ekspresji narracyjnej wykładu, jego sugestywności, obrazowości i zdolności apelowania do sfery uczniowskiego postrzegania świata. Może się także zaznaczać w aksjologicznej spójności i szerokości horyzontu przekazywanej uczniom wiedzy o literaturze. Suma tych właściwości narracji podręcznikowej składa się na bardziej lub mniej przekonującą propozycję kontaktu autora z osobą młodego odbiorcy.

Wyobrażenie ucznia jest tym pierwiastkiem podręcznika, który wyznacza charakter całej jego dydaktycznej konstrukcji. Jeśli sięgniemy do świetnej książki Jozefa Bachórza o pozytywizmie (Bachórz 1995), to zorientujemy się łatwo, że autor, profesor uniwersytecki, ale mający za sobą kilkanaście lat pracy nauczyciela licealnego, zachował wiarę w ambicje poznawcze uczniów, w ich zainteresowanie literaturą oraz zdolność do wysiłku samokształceniowego. Odrywa zupełnie tok swojego wykładu od strefy żywego nauczania: rysuje szeroki obraz tła historyczno-kulturowego i filozoficznego epoki, programów i debat literackich, prądów realizmu i naturalizmu w sztuce. Nie waha się przedstawić własne, unikające szkolnych schematów interpretacje dzieł wyznaczonych programem, rezygnując z jakichkolwiek instrukcji i pytań mogących sugerować kierunek pracy lekcyjnej. Podaje też zwięźle zredagowane informacje o innych ważnych utworach oraz tematach rozważanych w piśmiennictwie epoki. Dba przy tym o wyposażenie podręcznika w zestaw materiałów służących pracy samokształceniowej - spisy lektur dla zainteresowanych, obfite zestawy zagadnień do rozważania, tablicę synchroniczną wydarzeń historycznych i kulturalnych czy wreszcie antologię różnych tekstów publicystycznych, literackich, prasowych umożliwiającą uczniom konfrontację treści wykładu z dokumentami życia epoki.

Bachórz zbudował zatem podręcznik, który zupełnie nie towarzyszy lekcjom literatury, stanowi narzędzie uczenia się odrębne, z dużym nadmiarem eksponujące treści wymagane programem kształcenia. Zaadresował książkę - chyba zbyt ryzykownie - do ucznia pracującego samodzielnie; nie tego realnego uczestnika lekcji polskiego, ale wykreowanego nauczycielską wyobraźnią uczestnika kultury, gotowego do wysiłku zaspokajania swych zainteresowań.

Równie interesująco i zarazem ryzykownie rzecz się rysuje w otwierającym krakowską serię „Pod Globusem” podręczniku Andrzeja Borowskiego (Borowski 2002). Obraz zjawisk literatury i kultury od antyku po epokę oświecenia przeznaczony dla początkujących licealistów, a niezwykle rozbudowany erudycyjnie (zarysowany na 500 stronicach) zupełnie nie przystaje do realnie możliwego cyklu lekcji literatury. Uderza natomiast 
$\mathrm{w}$ tym podręczniku $\mathrm{z}$ wielkim talentem narracyjnym prowadzony wykład z częstymi zwrotami do odbiorców - wykreowany z wyobraźnią dydaktyczną nurt mądrej, nauczającej rozmowy profesora $\mathrm{z}$ zainteresowanym kulturą uczniem.

Pozostałe książki z serii „Pod Globusem” są odmiennie zaadresowane: realizują zamówienie wydawnicze na kompendium dostarczające uczniowi wiadomości o literaturze określonego okresu $\mathrm{w}$ zgodzie $\mathrm{z}$ programem i tokiem szkolnego nauczania. Warto przy tym jednak dodać, że wydawnictwo zwolniło całkiem twórców książek od zobowiązań dydaktycznych, pozostawiając im tylko role autorów merytorycznych informacji o przedmiocie, a zadanie projektowania obudowy dydaktycznej ich wykładu powierzając specjalistom od nauczania - metodykom. To charakterystyczna ilustracja aktualnych tendencji do izolowania teoretycznych i historycznych rozważań o literaturze od nurtu myśli o uczeniu się i nauczaniu literatury, stawiającego wymagania wyobraźni.

W podręcznikach powstających w kręgu szkolnego warsztatu pierwiastek wyobraźni dydaktycznej odgrywa kluczową rolę. Wynika to z profesjonalnego spojrzenia autorów na proces organizowania lekcyjnych spotkań uczniów z wielowymiarową materią literatury, języka, otaczającej ich przestrzeni kulturowej. Projektowanie tego procesu dydaktycznego musi mieć na uwadze konieczność zintegrowanej realizacji zobowiązań kształceniowych przedmiotu w wielu jego wymiarach: instrumentalnym, historycznym, społecznym, filozoficznym, estetycznym. Musi też zapewniać odpowiednią pozycję przekazowi wiedzy o literaturze i języku, przekazowi dokonywanemu jednak w trudniejszej, bo nie liniowej, ale rozproszonej postaci. Musi wreszcie przewidywać sposoby realizowania funkcji podręcznika - informacyjnej, badawczej, transformacyjnej i samokształceniowej.

$\mathrm{Na}$ poziom aktywności i ukierunkowanie wyobraźni dydaktycznej wpływa wiele czynników. Ma ona niewątpliwie podstawę w zróżnicowanych strukturach umysłów nauczycieli. Badający ten problem Stanisław Dobrowolski zauważył:

Z elementów wchodzących w skład procesu nauczania i wychowania - uczeń jako taki - najbardziej pociąga umysły intuicyjne, wartości kulturalne - umysły rozumowe (nauka) i wyobraźniowe (sztuka), sam proces nauczania i wychowania najsilniej pociąga umysły organizacyjne, praca ucznia - systematyczne, wreszcie zainteresowanie osoba nauczyciela - umysły ekspresyjne (Dobrowolski 1959, 353).

Rzucają te spostrzeżenia światło na podłoże różnic między podręcznikami w akcentowaniu określonych aspektów kształcenia polonistycznego.

Niezależnie od tych naturalnych skłonności o właściwościach i sile wyobraźni dydaktycznej rozstrzyga potencjał intelektualny oraz zasób doświadczeń zawodowych i społecznych nauczyciela. A więc wiedza 
o strukturze przedmiotu oraz horyzontach kształcenia, jakie mogą się otwierać w procesie jego poznawania, przeżywania i doświadczania wartości. Orientacja w metodologii badania i interpretowania dzieł i zjawisk języka, literatury, kultury oraz znajomość zjawisk społecznej komunikacji. Wiedza o procesie uczenia się i metodach kształcenia. A ponadto - co szczególnie istotne w aktach „żywego" nauczania - umiejętność dostrzegania związków między treściami nauczania przedmiotu a zjawiskami życia otaczającego aktualnie szkolny proces dydaktyczny, a także zdolność postrzegania ucznia jako jednostki, która wchodząc w skład szkolnej społeczności, „wnosi do życia zbiorowego klasy wszystko to, z czego wyrosła, wnosi całe swe <zaplecze> społeczne i kulturowe" (Mysłakowski 1971, 188).

Zaprojektowane z myślą o działaniu dydaktycznym nowatorskie podręczniki mają niewątpliwie podwójnego adresata. Uczniowi proponują wykonywanie kolejnych kroków (lektury tekstów, ich analizowania, twórczej transformacji, wykonywania różnych ćwiczeń, zadań itp.) umożliwiających mu poznanie i zrozumienie dzieł, zjawisk i problemów literatury, wejście w świat sztuki i wartości, nabywanie wielu umiejętności i sprawności itp. Przed nauczycielem natomiast otwierają drogę do obserwowania metody, jaką podręcznik prowadzi ucznia do tych pożądanych efektów, a tym samym wzbogacania własnej dydaktycznej wyobraźni.

Są w tych projektach modelowania podręcznika jako narzędzia pracy lekcyjnej liczne propozycje działań twórczych, angażujących chęć i zdolność wywoływania emocji, pobudzania wrażliwości i wyobraźni uczniów; odwoływanie się w toku analizy i interpretacji utworów do czytania, wygłaszania czy teatralizacji tekstu dla pobudzenia estetycznych lub moralnych przeżyć; akcentowanie szczególne walorów obrazowego i żywego języka wypowiedzi; wykorzystywanie siły oddziaływania obrazów. To wszystko może inspirować nauczyciela, skłaniać do otwarcia lekcji na sferę aktywnego uczestnictwa w kulturze.

Równolegle z apelem do emocji i twórczego działania propozycje podręczników otwierają się szeroko na intelektualną aktywność ucznia, jego myślenie problemowe. Pojawiają się w nich zwłaszcza bardzo często zaproszenia do uczestnictwa w dialogach ponad wiekami, oparte na wykorzystywanym od dawna pomyśle „kontynuacji i nawiązań, a więc na zderzaniu tekstów kultury z odległych wobec siebie epok pozwalającym na wzajemne ich oświetlanie się, na odkrywanie zeskakująco zbieżnych albo przeciwstawnych pierwiastków. Uważna obserwacja takich rozmaicie zaprojektowanych w podręczniku zderzeń pozwala nauczycielowi odkrywać różne możliwości ich interpretowania: czy to jako wypowiedzi o człowieku, jego postawach i problemach, czy jako obrazu przemian kultury, czy też jako przykładu odmiennych konwencji artystycznych itp. Pytania o kierunek interpretacji owych konstrukcji stawiają więc wyobraźnię nauczyciela 
przed koniecznością przezwyciężania własnego nawyku do liniowej prezentacji w chronologicznym porządku dzieł i zjawisk twórczości.

Daleko większym wyzwaniem dla wyobraźni uformowanej tradycją historycznoliteracką stają się przypadki podejmowania rewizji utrwalonych wyobrażeń o hierarchii celów i organizacji procesu kształcenia. Przykładem może służyć poznański podręcznik dla liceum Skarbiec języka, literatury, sztuki, który w kolejnych tomach wypisów odwraca tradycyjny porządek omawiania epok (zaczyna od współczesności, kończy na średniowieczu), a w każdym z nich zrywa z historycznoliteracką chronologią, podporządkowując zarysy obrazu przemian literatury ujęciom problemowym. Na tej zasadzie w tomie poświęconym obrazowi kultury XIX wieku pojawiają się rozdziały poświęcone podstawowym problemom epoki, a nie kolejnym okresom literackim. Tak na przykład rozdział Przyjaźń i miłość (Skarbiec... 2003, 93-150) ukazuje ów istotny dla ludzkiego życia problem na przykładach tekstów romantyków, erotyków młodopolskich i zaczerpniętych z powieści końca wieku realistycznych obrazów małżeńskich rozrachunków. Co więcej - każda z tych prezentacji jest dodatkowo wzbogacana kontekstowymi urywkami wypowiedzi artystów, publicystów, filozofów z różnych czasów - od antyku po współczesność - puentującymi humanistyczną wagę problemu. Taka konstrukcja podręcznika wręcz atakuje wyobraźnię nauczyciela, każe mu szukać nici spajających myślowo nowatorską, problemową koncepcję mówienia z uczniem o problematyce przemian literatury w ciągu kolejnych epok kulturowych.

Na inny sposób podważają przyzwyczajenia nauczyciela do historycznoliterackiego porządku omawiania utworów pomysły wiązania pracy nad tekstami literatury i kultury z aktywizacją myślenia uczniów o problemach otaczającego ich życia. Wyrazistych przykładów tak organizowanej pracy dostarcza licealny podręcznik To lubię!, poprzedzający i zamykający poszczególne rozdziały problemowe poleceniami wykonania tzw. „zadań dla uczniów". Tak np. w tomie przeznaczonym dla klasy drugiej rozdział zatytułowany Na wielkim targu świata (Kłakówna, Kołodziej, Łubniewska, Waligóra 2002, 5-74) otwiera się zadaniami opartymi na notatce prasowej o przypadkach oszustw w zbieraniu pieniędzy na pomoc społeczną oraz poleceniem zgromadzenia obserwacji na temat wiarygodności akcji charytatywnych, specyficznej „sprzedaży cierpienia”, komercjalizacji wartości itp. Po takim przygotowaniu problemowym pojawiają się dopiero teksty literackie, poruszające różne aspekty społecznego tematu sygnalizowanego tytułem rozdziału: fragmenty Molierowskiego Skapca, kazania sejmowego Skargi, Mistrza i Małgorzaty Bułhakowa, Wizyty starszej pani Dürenmatta, Miłosierdzia gminy Konopnickiej oraz wiersz Herberta Pan Cogito rozmyśla o cierpieniu i reprodukcje obrazów Rembrandta i Matejki. Zamykają tę sekwencję końcowe zadania dla ucznia, poświęcone idei wolontariatu.

Taka konstrukcja rozdziału (podobnie i innych) stanowi dla wyobraźni dydaktycznej nauczyciela nie lada wyzwanie. Wertując zestaw tekstów, 
mógł się najpierw zdziwić, a nawet zgorszyć, że nie służą one właściwie omawianiu przewidzianych programem dla drugiej klasy zagadnień romantyzmu i pozytywizmu, a potem jednak odkryć, że chodzi tu o inną zgoła, problemową koncepcję rozmawiania o literaturze w wymiarze egzystencjalnym ludzkiego bytowania. Na koniec dopiero zrozumieć i docenić wartość dydaktyczną stawianych uczniom na wstępie zadań dla pogłębienia interpretacji utworów z perspektywy uczniowskich obserwacji aktualnych zjawisk życia społecznego. Mógł też jednak ominąć całą tę drogę oswajania się z nowatorską koncepcją przedmiotu, sięgając po wyjaśnienia do towarzyszącej podręcznikowi „książki nauczyciela”.

Edytorskim zabiegom ożywiania stronic podręczników barwnymi reprodukcjami dzieł malarstwa towarzyszyły różnie ukierunkowane pomysły ich wykorzystywania w kształceniu polonistycznym. W świetle badawczych analiz tej praktyki (Bortnowski 2002, 124-132; Sporek 2007, 367-278) można je ustopniować w skali wartości - od przywołań obrazów jedynie w roli kulturowego kontekstu dla określonych zjawisk literatury, przez ich instrumentalne traktowanie jako podstawy rozmaitych ćwiczeń rozwijających sprawność wypowiedzi oraz zdolność przekładu znaków ikonicznych na słowo, aż do rozwijania wyobraźni i wrażliwości ucznia w pracy nad odbiorem dzieł malarstwa czy też w procesie kontekstualnej interpretacji dzieł literackich. Myśl dydaktyczna zawarta w konkretnych projektach spójnego działania na tekstach literatury i kultury ma szanse długiego oddziaływania, mimo że wyjątkowo twórczą generację licealnych i gimnazjalnych podręczników odstawiono już przedwcześnie na archiwalne półki.

Podobne możliwości wpływania na wyobraźnię dydaktyczną mają inspirowane myślą o integracji szkolnej polonistyki inicjatywy wiązania pracy nad tekstami literatury i kultury z kształceniem językowym. Są także w różnym stopniu zaawansowane. Przejawiać się mogą - jak to obserwujemy na przykład w podręczniku Słowa i teksty (Łazińska, Zdunkiewicz-Jedynak, Klejnocki 2003) - wyrazistą konstrukcją książki, sygnalizującą zamysł takiej integracji, dostarczającą przydatnych materiałów lecz nie przekraczającą bariery postulatywności. W tomie kreślącym obraz literatury i kultury XIX wieku sąsiadują tu z sobą naprzemiennie rozdziały poświęcone $\mathrm{z}$ osobna literaturze i nauce o języku (trzy omówieniu romantyzmu, pozytywizmu i epoki młodopolskiej oraz aż sześć różnym aspektom wypowiadania się pisemnego). Wnętrza rozdziałów poświęconych językowi są wypełnione zestawieniami tekstów naukowych, literackich, dziennikarskich, eseistycznych itp. opisujących zjawiska teoretycznie, ujmujących je w kontekście kulturowym, wartościujących czy też wykorzystujących artystycznie.

Zalety takiej konstrukcji podręcznika - gdy spojrzeć na nią z perspektywy rozwijania wiedzy o strukturze językowej tekstów oraz świadomości posługiwania się słowem - są oczywiste. Nie spełnia ona jednak nadziei na głębszą integrację polonistycznego kształcenia, choć inspiruje. 
Poszukiwanie drogi wiązania i scalania informacji zawartych w tekstach pozostawia wyobraźni i kreatywności nauczyciela.

Szanse głębszego wprowadzania uczniów w relacje między sferą poznawania języka i nabywania komunikacyjnej sprawności oraz budowania więzi z literaturą i kulturą pojawiają się wraz z tworzeniem podręczników (Kłakówna 1993; Kłakówna, Steczko, Wiatr 2004) - specjalnie zorientowanych na działanie, na rozwijanie $\mathrm{w}$ toku prac nad redagowaniem tekstów kompetencji nadawczych i odbiorczych uczniów w żywym, intensywnym kontakcie z materią językowego tworzywa literatury. W podręcznikach budowanych z myślą o realizacji szerokiej gamy zadań kształcenia literacko-kulturowego nie starcza na ogół miejsca dla takich działań. Wykorzystują je w pewnym stopniu autorzy dodatkowych części podręcznika, książek wiążących mocniej kształcenie sprawności językowej z próbami oświetlania wypowiedzi z perspektywy wiedzy systemowej o języku.

Problem nauczania przez działanie i związany z nim apel do wyobraźni dydaktycznej nauczyciela przewijał się przez wszystkie przywołane tu podręcznikowe propozycje projektowania i organizowania godzin polskiego. Odsłania to wyraźnie i uwydatnia ważną współcześnie ideę podręcznika jako narzędzia żywego nauczania.

Pracę nad budowaniem podręczników można, a chyba i należy traktować jako szczególny rodzaj twórczości. Trudno jednak nie zauważyć, że w różnych rankingach, akademickich punktacjach czy wykazach osobistego dorobku naukowego owoce tej twórczości, jeśli już są obecne, to stoją w cieniu listy rozpraw, artykułów, przyczynków mieszczących się w kategorii prac naukowych. Trudno się także takiemu porządkowi przeciwstawić. Pewnym pocieszeniem może jednak służyć opinia filozofa - prakseologa, który tak oto ujmuje relację między pojęciami twórczości i pracy: „Twórczość pracą nie jest, lecz równoważna jest pracy ze względu na doniosłość w czynieniu zadość potrzebom istotnym" (Kotarbiński, 1973, 81). Można to ujęcie problemu z powodzeniem odnieść do charakteru pracy naukowej dydaktyków literatury i języka oraz nauczycieli, tam gdzie wiąże się ona z tworzeniem narzędzi kształcenia.

Nowatorskie, apelujące do wysiłku wyobraźni dydaktycznej konstrukcje podręcznikowe mogą się spotykać z niezrozumieniem i niechęcią ze strony nauczycieli o słabo rozwiniętej kulturze literackiej, tradycyjnych upodobaniach, utrwalonym nawyku pasywności itp. Bez wątpienia - i kultury literackiej, i dydaktycznej wyobraźni należy uczyć, są z sobą mocno związane; rozwijałem tę myśl przed kilku laty w Poznaniu, ukazując przykłady horrendalnie opacznego interpretowania przez studiujących nauczycieli podręcznikowych propozycji pracy nad utworami (Uryga 2005, 53-64; 2008, 59-68). Recepcję takich nowatorskich podręczników warto by badać, 
biorąc pod uwagę to, jak potencjał wyobraźniowy podręcznika odzwierciedla się w odbiorze nauczycieli o różnym przygotowaniu intelektualnym, strukturach umysłu czy stażu zawodowym.

Analiza konkretnych konstrukcji podręcznikowych może mieć większą moc oddziaływania na warsztat dydaktyczny nauczyciela aniżeli teoretyczne rozważania i wskazówki kompendiów metodyki nauczania. Z tego względu warto by pomyśleć o budowaniu antologii, które gromadziłyby na użytek kształcenia polonistów wydobyte z podręczników, szczególnie wyraziste i instruktywne sekwencje projektowanych działań dydaktycznych. Pozwoliłoby to zwiększyć szanse dłuższego, wykraczającego poza doraźność oddziaływania myśli dydaktycznej zawartej w wybitnych dziełach podręcznikowych, które bywają już tylko obecne w pamięci byłych uczniów czy pedagogów albo na półkach bibliotecznych (do chwili kolejnego czyszczenia zbiorów).

\section{Bibliografia}

Bachórz Józef, 1995, Pozytywizm. Podręcznik dla szkół ponadpodstawowych, Warszawa.

Borowski Andrzej, 2002, Literatura polska i powszechna. Starożytność - Oświecenie. Podręcznik dla klasy 1, Kraków.

Bortnowski Stanisław, 2002, Modele prezentacji malarstwa, grafiki, rysunku $w$ podręcznikach gimnazjalnych, w: Podręcznik jako narzędzie kształcenia polonistycznego w gimnazjum, Kosętka H., Uryga Z. (red.), Kraków, s. $124-132$.

Budrewicz Zofia, 2003, Czytanka literacka $w$ gimnazjum międzywojennym. Geneza, struktura, funkcje, Kraków.

Czerniewski Wiktor, 1960, Wartości dydaktyczne podręczników historii literatury polskiej okresu międzywojennego, w: Czerniewski W., Słodkowski W., $Z$ zagadnień dydaktyki języka polskiego w klasach licealnych, Warszawa, s. 9-113.

Dobrowolski Stanisław, 1959, Struktury umysłów nauczycieli, Warszawa.

Ingarden Roman, 1939, O roli podręcznika $w$ nauczaniu $w$ szkole średniej, „Muzeum”, z. 2.

Kłakówna Zofia Agnieszka, 1993, Sztuka pisania. Ćwiczenia redakcyjne dla klas $I V-V I$, Warszawa.

Kłakówna Zofia Agnieszka, Kołodziej Piotr, Łubieniewska Ewa, Waligóra Janusz, 2002, To lubię!. Podręcznik do języka polskiego. Kształcenie kulturowo-literackie. Klasa II liceum, Kraków, s. 5-74.

Kłakówna Zofia Agnieszka, Steczko Iwona, Wiatr Krzysztof, 2004, Sztuka pisania. Podręcznik do języka polskiego. Klasy 1-3 gimnazjum. Ćwiczenia redakcyjno-stylistyczne. + Książka nauczyciela, Kraków.

Kotarbiński Tadeusz, 1973, Traktat o dobrej robocie, Wrocław.

Literatura i wychowanie. Z dziejów edukacji literackiej w Galicji, 1983, Inglot M. (red.), Wrocław. 
Łazińska Barbara, Zdunkiewicz-Jedynak Dorota, Klejnocki Jarosław, 2003, Słowa i teksty. Język polski. Podręcznik. Literatura i nauka o języku. Szkoły ponadgimnazjalne. Klasa 2, Warszawa.

Marchewa Janusz, 1990, Nauczanie literatury w szkole średniej w latach 19181939, Warszawa.

Mysłakowski Zygmunt, 1971, Pojęcie sytuacji dydaktycznej, w: Pisma wybrane, Warszawa.

Okoń Wincenty, 1973, Funkcja i treść podręcznika szkolnego, w: Z warsztatu podręcznika szkolnego, Parnowski T. (red.), Warszawa.

Skarbiec języka, literatury, sztuki. Wypisy z ćwiczeniami. Kultura XIX wieku i jej tradycje. Podręcznik dla klasy II liceum, 2003, Chrząstowska B. (red.), Poznań, s. 93-150.

Słowiński Lech, 1991, Szkolne podręczniki literatury a koncepcje kształcenia $w$ dwudziestoleciu międzywojennym, w: Podręczniki literatury $w$ szkole średniej. Wczoraj - dziś - jutro, Chrząstowska B. (red.), Poznań, s. 35-72.

Słowiński Lech, 1976, Nauka literatury polskiej w szkole średniej w latach 1795-1914, Warszawa.

Sporek Paweł, 2007, Formuła edytorska ikonografii we współczesnych podręcznikach gimnazjalnych, w: Podręczniki do kształcenia polonistycznego $w$ zreformowanej szkole - koncepcje, funkcje, język, Synowiec H. (red.), Kraków, s. 367-378.

Uryga Zenon, 2008, Wokół problemu wyobraźni dydaktycznej (o czytaniu podręcznika szkolnego przez studentów zaocznej polonistyki), w: Między szkoła a uniwersytetem. Odbiorcy w nowych podręcznikach dla reformujacej się szkoły, Kwiatkowska-Ratajczak M., Wantuch W. (red.), Poznań, s. 59-68.

Uryga Zenon, 2005, Z Indianami na ścieżce dydaktycznej diagnozy, w: Diagnostyka edukacyjna. Niemierkowskie spotkania i inspiracje, Groenwald M. (red.), Gdańsk, s. 53-64.

Wichary Gertruda, 1991, Koncepcja kształcenia literackiego w podręcznikach szkolnych Lucjusza Komarnickiego i Manfreda Kridla, w: Podręczniki literatury w szkole średniej. Wczoraj - dziś - jutro, Chrząstowska B. (red.), Poznań, s. 73-82.

Wichary Gertruda, 1979, O potrzebie badań nad podręcznikiem języka polskiego, w: Kształtowanie świadomości literackiej uczniów, Inglot M. (red.), Wrocław, s. 47.

\section{O Autorze}

Zenon Uryga, emerytowany profesor zw. Uniwersytetu Pedagogicznego w Krakowie, były rektor Uczelni (1990-1993), przez wiele lat kierownik Katedry Dydaktyki Literatury i Języka Polskiego, autor Odbioru liryki w klasach maturalnych (1982) i Godzin polskiego (1996) oraz innych studiów dydaktycznych, współautor Bibliografii metodyki nauczania języka polskiego $(1963,1974)$. 